Article

\title{
Creating a Map of the Social Functions of Urban Green Spaces in a City with Poor Availability of Spatial Data: A Sociotope for Lodz
}

\author{
Edyta Laszkiewicz *(D), Piotr Czembrowski and Jakub Kronenberg(1) \\ Social-Ecological Systems Analysis Lab, Department of Regional Economics and Environment, Faculty of \\ Economics and Sociology, University of Lodz, 90-237 Lodz, Poland; piotr.czembrowski@uni.lodz.pl (P.C.); \\ jakub.kronenberg@uni.lodz.pl (J.K.) \\ * Correspondence: edyta.laszkiewicz@uni.lodz.pl
}

Received: 15 April 2020; Accepted: 1 June 2020; Published: 2 June 2020

check for updates

\begin{abstract}
Many cities lack complex spatial databases that can answer the question "What does a given green space offer?" This complicates the lives of inhabitants, planners, and local authorities. One of the ways to obtain a complex picture of urban green spaces is to link multiple data sources. This article presents such an attempt to link multiple data sources to obtain a map of the social functions of urban green spaces in a city without a comprehensive spatial database on urban green spaces. We do so by adapting a method of mapping the social functions of urban green spaces-sociotope mapping-to the Central-Eastern European city of Lodz (Poland). Our results feature a map of the main social functions of urban green spaces (divided into five categories: nature, physical activity, social, play, and aesthetics) and GIS databases, with spatially explicit information on the 48 attributes of 196 urban green spaces in Lodz. According to our results, the greatest effort in sociotope mapping involves collecting data from different sources as it requires collaborating with various stakeholders-the owners of the data. Our study fits into the general trend of linking official data from municipal records with additional data on inhabitants' preferences for urban green space planning and management.
\end{abstract}

Keywords: GIS; spatial databases; sociotope mapping; green space management; urban planning

\section{Introduction}

Where is the nearest playground to where I live? Do people in this particular district have enough green spaces that cater to the needs of dog walkers? These and other questions are often asked by urban inhabitants and decision-makers alike. There is a growing need to provide access to the in-depth spatial data on urban green spaces, which could support decisions made by urban planners $[1,2]$ and assist urban inhabitants in their recreational activities [3]. Meanwhile, in spite of the increasing availability of various data sources on green space coverage-often free of charge-both processed (such as Urban Atlas) and unprocessed (such as remote sensing images from Landsat or Sentinel), we can still observe several obstacles in the practical use of these data. None of them, used as a single data source, can guarantee a complex picture of urban green spaces [1]. In addition, these databases do not offer any supporting information on urban green space features, such as their social functions, which are important from the perspective of potential green space users.

The lack of one spatial database, which could inform, "what does a given green space offer/what is there?" has several consequences for everyone: the inhabitants, the planners, and the authorities. When it comes to the potential users of green spaces, scarce and dispersed information may affect their willingness to use these places for recreational purposes and decrease the perceived attractiveness of certain green spaces. Therefore, easy and free access to comprehensive information about the social 
functions of urban green spaces is as important for encouraging people to use green spaces as their physical or psychological accessibility [3].

From the perspective of planners and authorities, a spatial database which combines all of the information about urban green space functions could support the planning and management of urban green spaces to respond better to the users' needs, and ensure equitable access to urban ecosystem services and green space amenities and facilities $[4,5]$. Additionally, it could facilitate communication between city authorities and inhabitants, and between different units within local administrations. Among other things, by using such a database, the authorities could inform inhabitants about activities planned in the green spaces. Furthermore, this database could improve the exchange of information and further strengthen cross-sectoral collaboration and even cooperation within the same institution responsible for urban green space management [6-8]. This is because different people would use the same inventory, offering a clear view of who has already done what within a given space (assuming a clear division of responsibilities for different aspects of urban green space management), or at least providing information on what is there (or in the case of the unclear division of responsibilities, indicating the need to coordinate activities with other actors that would potentially need to be identified).

In response to the above, more recently, the emphasis has been on combining different data sources to obtain a complex picture of urban green spaces, including volunteered geographic information such as OpenStreetMap or social media data [9-11] and data collected using the public participation GIS approach $[12,13]$. As was recently demonstrated, the use of multiple data sources may improve the mapping of urban green spaces $[1,14]$ and support urban green space classification and management [15-17]. Linking different data sources into one complex spatial database that covers different types of urban green spaces should go beyond the basic information on the spatial distribution of green spaces and towards the exact location of their diverse biotic, abiotic, and man-made components. This would further support an understanding of the spatial distribution of the social functions and recreational values of urban green spaces. Indeed, such a combination of different sources of information has been followed in the case of new applications of public participation GIS [18].

When it comes to mapping the social/recreational functions of urban green spaces in a city, otherwise characterised by a poor availability of data, one way to demonstrate the usefulness of using multiple data sources regarding urban green space features is through the application of different mapping methods. Our article presents an attempt to link multiple data sources to obtain a map of the social functions of urban green spaces in a local context. We did so by adapting and applying a method of mapping the social functions of urban green spaces—sociotope mapping [19] — to the Central-Eastern European city of Lodz (Poland), which is characterised by scattered and fragmented data on urban green spaces, and so far has lacked a comprehensive spatial database on the social functions of these spaces. In particular, we created a map of the social functions of parks and green squares in Lodz and, based on the process of building this map, we discuss how a sociotope map can benefit from linking multiple data sources, and in what way it provides a particularly comprehensive picture of urban green spaces.

The rest of the paper is organised as follows: Section 2 contains an overview of the methods used for mapping the social/recreational functions of urban green spaces, with a focus on combining different data sources; in Section 3, we introduce sociotope mapping, starting with its origins, through the first application in Stockholm, and ending with how we adapted it in the case of Lodz; Section 4 describes the procedure of data collection and processing; in Section 5 we present the map of the social functions of parks and green squares in Lodz; in Section 6, we discuss our findings from the perspective of increasing the availability of data on urban green spaces in Lodz and, more generally, linking multiple data sources for an enhanced picture of urban green spaces to support urban planning and management; Section 7 concludes. 


\section{Methods of Mapping the Social Functions of Urban Green Spaces}

Over the past 30 years, describing urban green spaces from the perspective of their recreational or social functions has gained popularity among researchers and urban planners, especially in the Nordic countries [20]. Therefore, several methods for mapping these functions have been proposed and implemented, such as park character analysis [21], mapping positive recreational experiences in urban green spaces (REC-mapping [22], social value mapping [23], or sociotope mapping [19], to mention just a few). However, they all differ in their definition of 'social/recreational function', which further affects the mapping procedure, including the data collection and the usefulness of the map for urban planners and citizens.

Some of these methods, such as REC-mapping or social value mapping, refer to the perception of recreational experience in urban green spaces expressed by the city's inhabitants. In these cases, the necessary data come from GIS surveys and self-reported information on the presence and strength of recreational experiences regarding selected green spaces or parts of them. These potential experiences may be pre-grouped into general items, as in the REC-mapping [22] or described using the respondents' own language, as can be done in softGIS [12]. Although these methods can be used to map what is really important for green space users, they do not necessarily provide reliable or comprehensive answers regarding the amenities and functions present in the given green spaces. Besides, they require complex programming and typically involve problems with recruiting statistically representative samples of respondents.

Other methods, such as sociotope mapping or the relative importance score for structural elements of urban green spaces [24], combine users' perceptions/evaluations with multiple sources of secondary data on urban green space attributes/characteristics. The latter may be chosen based on spatial data availability and by the importance of the social/recreational function derived from the literature or elicited from experts $[19,24]$. For example, the relative importance score measure, applied to 547 green space polygons in Oslo, was based on 30 different attributes of green spaces, which represented biotic, abiotic, and man-made elements that appear in a given green space [24].

Combining information on the physical attributes of a green space from secondary spatial databases with users' perceptions has advantages, regardless of the mapping method [25]. The users' perceptions may be used to evaluate the importance of the known attributes of green spaces. For example, the relative importance score involves assessing 30 preselected green space features [24]. Alternatively, such as in sociotope mapping [19], information elicited from users may be used to extend the list of green space attributes. Linking these data sources makes it possible to capture several green space features that determine the social functions of these spaces, but which cannot be easily captured by secondary data (in some cases, they cannot even be imagined by green space planners). Such examples include the uniqueness of a green space, the feeling of silence, the possibility of watching birds, or even the best spots to fly drones. For many users, these features are no less important than physical equipment when it comes to creating the social functions of green spaces. After all, the users' perceptions are one of the key filters which mediate the flow of benefits from urban ecosystems, along with the relevant infrastructure and institutions [26].

Finally, urban green space attractiveness is perhaps most typically assessed based on composite indicators or systems of indicators that are completely based on expert assessments (e.g., ParkIndex measures factors, ranging from how to get to a park, its equipment, and appearance, to factors that negatively affect the perception of a given green space and its surroundings [27]). In Lodz, all parks and green squares were recently mapped from the perspective of barriers limiting their availability, accessibility, and attractiveness [4]. In the case of attractiveness, the focus was on expert-defined aspects, such as the existence of park infrastructure, leisure equipment, water, loud and crowded outdoor events, transportation noise, air pollution, the share of paved area, and the size of a given park. 


\section{Sociotope Mapping}

The "sociotope" concept was proposed by Alexander Ståhle and Anders Sandberg at the Stockholm City Urban Planning Administration in 2000. It was meant as an extension of the previously created "biotope" map, which focused on the ecological characteristics of public spaces, to cover human-related issues. While a biotope is "a small area with uniform biological conditions such as climate, soil or altitude" [28], a sociotope is understood as a space that is uniform in its use values and social meanings to a specific culture or group, such as a city's inhabitants. In particular, "sociotope" refers to the value of open space in the context of urban planning, assessment, and decision-making [19].

The first sociotope map of the social functions (or "use values" and "use value concepts", as referred to by the authors [19]) of open spaces in Stockholm was completed in 2002. Since then, the sociotope map for Stockholm has evolved and has been updated twice, in 2009 and 2014. In particular, the list of "use value concepts" and the number of open spaces evaluated in every subsequent sociotope mapping was extended. In addition, since the initial work of Ståhle and Sandberg, other Swedish municipalities have conducted sociotope mapping (e.g., Gothenburg [29], Östervåla [30], and Kungsbacka [31]). Our study is based on the sociotope mapping procedure used in Stockholm and adapted to the local conditions in Lodz.

The sociotope was initially developed as a tool to inform urban densification projects. Nevertheless, it gained broader popularity and became a common concept among Swedish urban planners who started to use sociotopes to increase their knowledge of the social functions of urban landscapes and to create guidelines for open space planning. For example, the sociotope mapping of the Annedal brownfield in Stockholm enabled urban planners to uncover social values, such as spaces for picnics and soccer, which were desired by the inhabitants living close to Annedal but which were missing [19].

\subsection{Sociotope Mapping in Stockholm}

Sociotope mapping in Stockholm was described in detail in the Sociotope Handbook [32]. The map was created in five steps and involved different stakeholders, such as the local authorities, researchers, and inhabitants. The procedure started by defining the spaces for which the social functions were to be investigated, followed by an evaluation of the listed spaces by local experts (e.g., landscape architects), then by the inhabitants, and ending with a synthesis of all the collected data and the creation of a GIS-based map featuring the social functions of these spaces.

In Stockholm, the map was created for every publicly accessible open space larger than 0.5 ha, the majority of which were green areas. These included parks and green natural areas and playgrounds, sports fields, etc. They were named and geographically located using existing spatial databases. The most recent 2014 map covered 1377 publicly accessible open spaces.

Each open space was assessed by the municipality's experts, including landscape architects, park historians, and the city's ecologists. These experts used multidimensional protocols based on scientific research and professional experience, along with their own observation of the spaces [19]. Furthermore, the social functions of open spaces were assessed by their users with the use of surveys, focus groups, and in-depth interviews. In particular, the inhabitants were asked to mark their favourite open spaces and assess their quality, accessibility, and potential deficiencies [32].

In the next step, all of the information collected from the experts and inhabitants was synthesised and compiled into a number of discrete "use value concepts" (20 in the first sociotope map, and 30 in 2014). The use value concepts referred to the broadly defined equipment, functions, and perceived features of open spaces. Examples included the possibility of contact with water, the availability of playgrounds or picnic areas, and the occurrence of events and they were further classified into six main categories: aesthetics, nature, physical activity, play, social, and water.

The last step of the sociotope mapping was to create a GIS-based map of the use values of open spaces, and it was possible to assign several different functions to each open space. The final map was published not only in paper format, but also on the administration's intranet, and as a web-publication on the internet to ensure easy access to the map for different stakeholders, most 
notably, the inhabitants [19]. The above procedure ensured that the sociotope became a useful tool that brought the seemingly qualitative topic of the attractiveness of publicly available open spaces for the inhabitants to a quantitative format.

\subsection{Sociotope Mapping in Lodz}

Our study is highly influenced by the Stockholm sociotope map, although it had to be adapted to a local context. We followed the five-step procedure used in Stockholm and describe each step in the following subsections.

Throughout the project, we collaborated with the local authorities responsible for the maintenance and management of the green spaces covered by our study. Our collaboration started in June 2018 with an initial meeting with the Urban Green Space Authority (ZZM). We proposed the idea of creating a sociotope map for Lodz, and we also discussed its basic tenets. A series of working meetings were held in autumn 2018, which focused on assessing individual green spaces, and they were followed by a workshop at the University of Lodz in December 2018, during which we discussed the draft version of the map with several stakeholders. Finally, in April 2019, there was a consultation of the pre-final online version of the map. Apart from ZZM, the list of the involved stakeholders included the Department of Municipal Management (WGK), the Municipal Sports and Recreation Center (MOSiR), the Municipal Planning Office (MPU), the Department of Revitalization of the City Office, the City Centre of Geodesy (LOG), and the Department of Project Management of the City Office. This was related to the complex management structure of urban green spaces in Lodz [7]. Collaborating with the local authorities was particularly important at the stage of the expert evaluation of urban green spaces, as described in Section 3.2.2.

\subsubsection{Definition of Green Spaces to Be Investigated}

Similar to the Stockholm sociotope map, we started by defining and listing the objects to be mapped. We decided to conduct an analysis for all of the formal green spaces managed by the city, such as parks, green squares, and recreational sites, with no limitation regarding their size. The initial list of formal green spaces was verified during the workshop in December 2018 and supplemented based on the suggestions of the workshop participants (in particular, we extended the list of green spaces by adding recreational sites). In the face of inadequate green space data in Lodz, to obtain the boundaries of these green spaces, we had to combine multiple spatial databases, as described in Section 4.1.

\subsubsection{Expert Evaluation}

We used scientific and expert knowledge to adapt the list of 30 "use value concepts" from the Stockholm sociotope map to the local context. Instead of "use value concepts", we prefer to refer to them as "attributes", a term that better serves the purpose of describing green spaces and their social functions.

In collaboration with the abovementioned local stakeholders, in particular during the direct meetings with the representatives of the relevant authorities responsible for the different green spaces, we verified the relevance of each green space attribute used in Stockholm and adapted it to the local context. In addition, after obtaining the initial sociotope map for Lodz, the respective stakeholders were asked for feedback regarding the assessment of the green space attributes. Their suggestions were used to improve the sociotope map, which was sent back to the officials who took an active part in its creation for verification. Their feedback informed the final corrections before the map was made publicly available.

Based on such a collaborative process, we decided to omit those attributes from Stockholm which were unique to Swedish culture and were not relevant to the green spaces in Lodz (e.g., folklife, outdoors markets, or cultivation). In addition, we decided to limit the number of aggregated categories to five: aesthetics, nature, physical activity, play, and social, omitting water. While water is abundant in Stockholm, the same cannot be said about Lodz. Although its name ("boat") harks back to the days 
when numerous small rivers allowed its textile industry to flourish in the 19th century [33], nowadays, there are very few water bodies which can be used for recreational purposes.

Our expert assessment resulted in 28 new attributes being added to the list used in Stockholm, which were important to reflect the social functions of the green spaces in Lodz. These 28 attributes included elements of infrastructure, such as amphitheatres, fountains, ping pong tables, chess tables, and sculptures, as well as the characteristics of green spaces identified by the inhabitants of Lodz: silence, wildness, spaciousness, and uniqueness, as described in the following subsection. The full list of the 48 attributes (20 taken from the Stockholm study and 28 city-specific) can be found in Table 1.

Table 1. The sociotope attributes in Lodz.

\begin{tabular}{|c|c|c|c|c|}
\hline No & Category & Attribute & Data Format & Data Source \\
\hline 1 & Aesthetics & Archaeological objects & Spatial point & NID \\
\hline 2 & Aesthetics & Flowerbeds & Spatial point & $\mathrm{ZZM}$ \\
\hline 3 & Aesthetics & Fountains & Spatial point & ZZM \\
\hline 4 & Aesthetics & $\begin{array}{l}\text { Historic architectural objects } \\
\text { (sculptures, villas, monuments, } \\
\text { remains of cemeteries, workers' } \\
\text { settlements, factories, etc.) }\end{array}$ & Spatial point & NID \\
\hline 5 & Aesthetics & Sculptures, monuments & Spatial point & $\mathrm{ZZM}$ \\
\hline 6 & Aesthetics & Silence & $\begin{array}{l}\text { Attribute of the } \\
\text { polygon }\end{array}$ & softGIS \\
\hline 7 & Aesthetics & Spaciousness, open space & $\begin{array}{l}\text { Attribute of the } \\
\text { polygon }\end{array}$ & softGIS \\
\hline 8 & Aesthetics & Interesting topographic features & $\begin{array}{l}\text { Attribute of the } \\
\text { polygon }\end{array}$ & softGIS \\
\hline 9 & Aesthetics & Uniqueness & $\begin{array}{l}\text { Attribute of the } \\
\text { polygon }\end{array}$ & softGIS \\
\hline 10 & Aesthetics & View, landscape & $\begin{array}{l}\text { Attribute of the } \\
\text { polygon }\end{array}$ & softGIS \\
\hline 11 & Aesthetics & Water & Spatial point & ZZM, MOSiR \\
\hline 12 & Nature & Animals & $\begin{array}{l}\text { Attribute of the } \\
\text { polygon }\end{array}$ & softGIS \\
\hline 13 & Nature & Greenness & $\begin{array}{l}\text { Attribute of the } \\
\text { polygon }\end{array}$ & softGIS \\
\hline 14 & Nature & Nature monuments & Spatial point & MPU \\
\hline 15 & Nature & Sounds of nature & $\begin{array}{l}\text { Attribute of the } \\
\text { polygon }\end{array}$ & softGIS \\
\hline 16 & Nature & Wildness & $\begin{array}{c}\text { Attribute of the } \\
\text { polygon }\end{array}$ & softGIS \\
\hline 17 & Other & $\begin{array}{c}\text { Other unique objects (e.g., single } \\
\text { places to play table football and } \\
\text { pétanque) }\end{array}$ & Spatial point & ZZM, WGK \\
\hline 18 & $\begin{array}{l}\text { Physical } \\
\text { activity }\end{array}$ & Bicycle stands & Spatial point & $\begin{array}{l}\text { Fenomen } \\
\text { foundation }\end{array}$ \\
\hline 19 & $\begin{array}{l}\text { Physical } \\
\text { activity }\end{array}$ & $\begin{array}{l}\text { Stations of the public bicycle } \\
\text { scheme }\end{array}$ & Spatial point & $\begin{array}{l}\text { Fenomen } \\
\text { foundation }\end{array}$ \\
\hline 20 & $\begin{array}{l}\text { Physical } \\
\text { activity }\end{array}$ & Bicycle paths & Spatial polyline & LOG \\
\hline 21 & $\begin{array}{l}\text { Physical } \\
\text { activity }\end{array}$ & Ice rinks & Spatial point & MOSiR \\
\hline 22 & $\begin{array}{l}\text { Physical } \\
\text { activity }\end{array}$ & Indoor pools & Spatial point & MOSiR \\
\hline
\end{tabular}


Table 1. Cont

\begin{tabular}{|c|c|c|c|c|}
\hline No & Category & Attribute & Data Format & Data Source \\
\hline 23 & $\begin{array}{l}\text { Physical } \\
\text { activity }\end{array}$ & Outdoor gyms & Spatial point & $\begin{array}{l}\text { ZZM, MOSiR, } \\
\text { WGK }\end{array}$ \\
\hline 24 & $\begin{array}{l}\text { Physical } \\
\text { activity }\end{array}$ & Paths for runners & Spatial polyline & ZZM \\
\hline 25 & $\begin{array}{l}\text { Physical } \\
\text { activity }\end{array}$ & Table tennis tables & Spatial point & $\begin{array}{l}\text { ZZM, MOSiR, } \\
\text { WGK }\end{array}$ \\
\hline 26 & $\begin{array}{l}\text { Physical } \\
\text { activity }\end{array}$ & $\begin{array}{l}\text { Sports fields (football, basketball, } \\
\text { volleyball, etc.), tennis courts }\end{array}$ & Spatial point & $\begin{array}{l}\text { ZZM, MOSiR, } \\
\text { WGK }\end{array}$ \\
\hline 27 & $\begin{array}{l}\text { Physical } \\
\text { activity }\end{array}$ & Routes for cross-country skiing & Spatial polyline & ZZM \\
\hline 28 & $\begin{array}{l}\text { Physical } \\
\text { activity }\end{array}$ & Sports events & $\begin{array}{l}\text { Attribute of the } \\
\text { polygon }\end{array}$ & Zielona Łódź \\
\hline 29 & $\begin{array}{l}\text { Physical } \\
\text { activity }\end{array}$ & $\begin{array}{l}\text { Water equipment rental (pedalos, } \\
\text { kayaks, etc.) }\end{array}$ & Spatial point & MOSiR \\
\hline 30 & Play & $\begin{array}{c}\text { Amusement parks (recreation } \\
\text { areas) }\end{array}$ & Spatial point & ZZM, MOSiR \\
\hline 31 & Play & $\begin{array}{l}\text { Natural playgrounds (including } \\
\text { rope courses, parks with wooden } \\
\text { infrastructure, etc.) }\end{array}$ & Spatial point & ZZM, MOSiR \\
\hline 32 & Play & Outdoor swimming & Spatial point & MOSiR \\
\hline 33 & Play & Playgrounds for children & Spatial point & $\begin{array}{l}\text { ZZM, MOSiR, } \\
\text { WGK }\end{array}$ \\
\hline 34 & Play & Pump tracks & Spatial point & MOSiR \\
\hline 35 & Play & Skateparks & Spatial point & MOSiR, WGK \\
\hline 36 & Play & $\begin{array}{l}\text { Sledging infrastructure (e.g., } \\
\text { artificial hills) }\end{array}$ & Spatial point & $\begin{array}{l}\text { ZZM, MOSiR, } \\
\text { WGK }\end{array}$ \\
\hline 37 & Play & $\begin{array}{l}\text { The possibility of practising water } \\
\text { sports }\end{array}$ & Spatial point & MOSiR \\
\hline 38 & Social & $\begin{array}{c}\text { Amphitheatres, bowers, art } \\
\text { galleries }\end{array}$ & Spatial point & ZZM \\
\hline 39 & Social & BBQ spots & Spatial point & ZZM, MOSiR \\
\hline 40 & Social & $\begin{array}{l}\text { Cafes, other catering facilities } \\
\text { (all-year-round) }\end{array}$ & Spatial point & ZZM, MOSiR \\
\hline 41 & Social & Baby changing facilities & Spatial point & ZZM \\
\hline 42 & Social & Chess tables & Spatial point & $\begin{array}{l}\text { ZZM, MOSiR, } \\
\text { WGK }\end{array}$ \\
\hline 43 & Social & Dog-friendliness & $\begin{array}{l}\text { Attribute of the } \\
\text { polygon }\end{array}$ & softGIS \\
\hline 44 & Social & $\begin{array}{c}\text { Entertainment events, concerts, } \\
\text { etc. }\end{array}$ & $\begin{array}{l}\text { Attribute of the } \\
\text { polygon }\end{array}$ & Zielona Łódź \\
\hline 45 & Social & Graduation towers & Spatial point & ZZM \\
\hline 46 & Social & $\begin{array}{l}\text { Mobile gastronomy (e.g., food } \\
\text { trucks, coffee bikes) }\end{array}$ & Spatial point & ZZM, MOSiR \\
\hline 47 & Social & $\begin{array}{l}\text { Paths for night walks (equipped } \\
\text { with lamp posts) }\end{array}$ & Spatial point & GESUT \\
\hline 48 & Social & Toilets & Spatial point & ZZM, MOSiR \\
\hline
\end{tabular}

\subsubsection{Evaluation by Society}

As an equivalent of the user evaluation performed in Stockholm, information on the additional attributes was derived from the public participation GIS study—the "Licz na zielen" Internet-based softGIS questionnaire. The study was conducted by the Sendzimir Foundation in 2014. In this study, 
1640 respondents from three large Polish cities (including 418 from Lodz) marked the green spaces which they considered particularly valuable on the respective maps of their cities. They were also asked to explain their assessments [12]. The verbal responses were then coded and aggregated into 21 categories from which we chose 10 to represent the different relevant attributes, as shown in Table 1.

\subsubsection{Synthesis}

The evaluations by the experts and the members of the public resulted in GIS-based files in three data formats: spatial points, spatial polylines, and attributes of polygons. The first two data formats indicate the exact spatial location of selected sociotope attributes within a given green space polygon, and they typically represent amenities and facilities, such as infrastructure or equipment. Polygon attributes characterise the whole green space rather than a specific location within it. Information gathered in these three data formats was synthesised in two ways. First, to create the GIS-based map, as detailed in Section 3.2.5 and Section 4.5, we acknowledged the different characteristics of the sociotope attributes and adjusted how they are represented on the map accordingly. The sociotope attributes (e.g., outdoor gyms or table tennis tables) for which the direct spatial location within green spaces could be indicated were presented in this way. Other sociotope attributes, such as greenness or uniqueness, were presented as general features of a whole green space. Second, to synthesise the results, we prepared a list of all parks, green squares, and recreational sites, indicating whether each of them could be characterised by a given sociotope attribute. As a result, we obtained a database with the full list of 196 green spaces, each of them with "yes"/"no" assignation to all 48 sociotope attributes.

These databases were used to create the sociotope map for Lodz. Based on our knowledge, we assigned each sociotope attribute to one of the five main sociotope categories: aesthetics, nature, physical activity, play, and social, as shown in Table 1 . Then, we assigned the urban green spaces to the abovementioned sociotope categories, based on the number of sociotope attributes which belonged to a given category and which appeared in a given urban green space. The number of sociotope attributes necessary for a given urban green space to represent aesthetics, nature, physical activity, play, or social was established independently for each of these categories, and it depended on the number of sociotope attributes in each category, as detailed in Section 4.4.

\subsubsection{Creation of a GIS-Based Map}

The next step of the sociotope mapping in Lodz was to create a GIS-based map of the social functions of green spaces. The map was a working document, and it was instantly updated during the meetings with the respective stakeholders. Within the iterative process described above, we collected feedback from the stakeholders and finally delivered the complete map to the City Centre of Geodesy to make it publicly available. As part of our discussions with the local stakeholders, we also covered the potential for the dissemination of the map among the city's inhabitants and local authorities, and its broader usefulness in urban planning.

\section{Data Collection and Processing}

\subsection{Green Space Boundaries}

The City Office of Lodz lacks a central database of green spaces. The data are likely to differ among the different sources, even when they pertain to the same categories of green spaces and the basic issues of their boundaries. The different institutions keep the data for their own purposes only, which reflects a broader problem of poor collaboration between the different actors involved in urban green space management in Lodz [7].

Therefore, the initial phase of data collection was to obtain a complete list of parks, green squares, and recreational sites with their boundaries in the GIS format. For this purpose, we took the boundaries of 115 formal green spaces, such as parks and green squares, provided by MPU and LOG. The boundaries of recreational sites were not included in the data from MPU or LOG, nor 
any other available data source. Therefore, with the collaboration of the WGK-the city's authority responsible for managing the recreational sites in Lodz-we drew the polygons of the respective 81 recreational sites. The sociotope map for Lodz covers 196 green spaces.

\subsection{Green Space Attributes-Expert Evaluation}

The collection of data on green space attributes involved several challenges as well. The main challenge was to identify and combine scattered and fragmented information from multiple sources. As indicated above, in Lodz, there is no single organisation responsible for the maintenance of all formal green spaces and no comprehensive spatial database of the social functions of urban green spaces. The parks and green squares are managed by ZZM, while most small recreational sites are managed by WGK. In addition, some other sites equipped with recreational and sports infrastructure are managed by MOSiR.

The data gathered from these units were mostly not georeferenced and not digitised. Therefore, obtaining information on selected attributes, such as elements of park infrastructure, was connected with digitising and geocoding the data. Furthermore, the institutions responsible for the management of a certain green space category did not have information regarding all of the predefined attributes. This required the involvement of other institutions which offered access to data on the missing attributes, such as LOG and the National Institute of Heritage (NID).

We collected the geographic data from ZZM on 20 attributes for 115 parks, as shown in Table 1. This mainly included information on recreational and sports infrastructure, such as routes for cross-country skiing or outdoor gyms. As the data were not stored in an electronic format, they had to be collected through interviews with separate officials responsible for the different parks. This resulted in a GIS-based map with the exact spatial location of the selected social functions in the form of spatial points and polylines within green space polygons.

ZZM also provided us with information on the cultural and sports events that take place in parks and green squares. This information came from the project "Green Łódź" ("Zielona Łódź"), developed within the ZZM and aimed at animating the social aspect of green spaces. We obtained the list of cultural and sports events, such as family picnics, photographic workshops, and botanical or historical walks, which had taken place in green spaces between 2013 and 2017. Most of them were organised only once, while others were organised systematically but in a different green space each year. In our map, we only indicated those events which reoccurred in a given space over time with some regularity-at least once a year for at least three consecutive years. We assigned this information to the seven respective green spaces in the form of the attributes of the polygons.

The information on the attributes of 81 recreational sites was mainly provided by WGK. The small recreational sites were mainly equipped with playgrounds, but some of them also had chess and table tennis tables or outdoor gyms. In addition, WGK provided information on the toilets in all formal green spaces. All of the data from WGK required digitisation and geocoding.

Additional information was obtained during interviews conducted with representatives from MOSiR. They provided us with information about sports equipment in additional recreational sites, including pump tracks and the possibility to rent water equipment such as pedalos and kayaks. As with the information gathered from ZZM and WGK, we had to digitise and geocode the data to obtain a GIS-based map with these attributes.

We linked the abovementioned data with those obtained from LOG and NID. Although these institutions are not responsible for green space management, they manage the data on additional attributes. In particular, LOG provided us with shapefiles of bicycle infrastructure: bicycle paths, bicycle stands, and the stations of the public bicycle scheme. These data were generated by the Fenomen Foundation. Additionally, LOG provided us with the locations of lamp posts, which allow for evening walks, which are part of the GESUT database (Geodetic Records of the Terrain Armaments Network), maintained at the national level by the Head Office of Geodesy and Cartography. NID provided shapefiles with registered monuments and archaeological sites. The locations of natural monuments were provided by MPU. 


\subsection{Green Space Attributes-Evaluation by Members of the Public}

In the "Licz na zielen" softGIS survey, 418 respondents from Lodz marked 399 spots in 51 green spaces considered in our database (many other spots fell outside of formal green spaces). These marks represented the places which, in the respondents' opinions, were characterised by silence, interesting topographic features, etc. The markings were unevenly distributed-two-thirds of them were located in 10 large parks, while the number of marks in the other parks was limited. The uneven distribution of marks might have resulted in the under-representation of some green spaces in terms of a given attribute. To avoid a given attribute appearing only in a few well-known green spaces characterised by a high number of markings in general, we decided to credit attributes to green spaces where at least one marking was made related to a given softGIS attribute. We put this information on the map in the form of the attributes of green space polygons.

\subsection{Synthesis}

Spatial data on sociotope attributes were synthesised in two ways, detailed in Section 3.2.4. We stored the sociotope attributes in the GIS-based data format separately for parks and green squares and recreational sites, divided into spatial points, polylines, and attributes of polygons. To avoid a high number of GIS-based files with scattered information, we allowed all sociotope attributes that represented one main sociotope category, as shown in Table 2, to be stored in one GIS-based file. The files synthesised in this way are available as Supplementary Material accompanying the present article.

Table 2. The synthesis of sociotope attributes for urban green spaces in Lodz. Shaded cells represent the number of sociotope attributes required to assign a given urban green space to a respective main sociotope category. For example, a green space is assigned to the sociotope category "aesthetics" if there are two, three, or more (up to eleven) sociotope attributes located within such a green space. The zero value means there could be the given number of sociotope attributes, but it was not observed in any green spaces.

\begin{tabular}{|c|c|c|c|c|c|}
\hline \multirow{2}{*}{$\begin{array}{l}\text { Number of } \\
\text { Sociotope } \\
\text { Attributes }\end{array}$} & \multicolumn{5}{|c|}{ Number of Urban Green Spaces with a Given Number of Sociotope Attributes } \\
\hline & Aesthetics & Nature & Play & Social & $\begin{array}{l}\text { Physical } \\
\text { Activity }\end{array}$ \\
\hline 12 & & & & & 0 \\
\hline 11 & 0 & & & 0 & 0 \\
\hline 10 & 0 & & & 0 & 0 \\
\hline 9 & 1 & & & 1 & 1 \\
\hline 8 & 4 & & 0 & 1 & 0 \\
\hline 7 & 0 & & 0 & 0 & 0 \\
\hline 6 & 2 & & 0 & 3 & 1 \\
\hline 5 & 5 & 2 & 3 & 3 & 3 \\
\hline 4 & 9 & 0 & 1 & 7 & 10 \\
\hline 3 & 7 & 8 & 2 & 12 & 16 \\
\hline 2 & 16 & 8 & 16 & 25 & 20 \\
\hline 1 & 22 & 32 & 111 & 83 & 38 \\
\hline 0 & 130 & 146 & 63 & 61 & 107 \\
\hline
\end{tabular}

In addition, we synthesised information on the sociotope attributes by assigning them to the main sociotope categories for each urban green space, respectively. In particular, based on the database with the binary assignation of each sociotope attribute to each green space ("it is present in this green space"/"it is not present in this green space"), we calculated the total number of attributes that could potentially be recorded in a given green space within each of the main sociotope categories. In Table 2, this is the highest number in the first column that corresponds to the row with a non-missing value for the respective sociotope category. This number varied from five for the "nature" category to twelve for the "physical activity". In addition, we calculated the real number of sociotope attributes located in each urban green space. In four out of the five main sociotope categories, no urban green space 
was characterised by all sociotope attributes possible in a given main sociotope category. For example, for the "play" sociotope category, the total potential number of sociotope attributes was eight, but in reality, the highest number of sociotope attributes assigned to the "play" category in a given green space was five, and this was observed in three urban green spaces only.

Subsequently, we set the number of attributes necessary to assess each urban green space as representing a given main sociotope category. For "aesthetics", "social", and "physical activity" (i.e., categories characterised by the highest number of attributes), we classified urban green space as representing a given sociotope category when at least two different sociotope attributes were located within this green space, represented by the shaded cells in Table 2. In the case of "nature" and "play", the total number of sociotope attributes was lower than for the other sociotope categories. Hence, only one sociotope attribute was sufficient to characterise a given urban green space as "nature"/"play". The results of the abovementioned classification are described in Section 5.

\subsection{Creation of a GIS-Based Map}

We stored the sociotope attributes in the respective GIS-based files. Those sociotope attributes for which the exact spatial location within a given urban green space was known (e.g., outdoor gyms or routes for cross-country skiing) were stored as spatial points and polylines. Other sociotope attributes, which provided the general characteristics of a given urban green space (e.g., all sociotope attributes derived from the softGIS survey), were stored as attributes of the respective green space polygons. The publicly available map of the social functions of parks, green squares, and recreational sites was published as one of the thematic maps in the official online Land Information System for Lodz (InterSIT) managed by LOG at: https://mapa.lodz.pl/portal/apps/webappviewer/index.html?id= 944f90f93e354c92ae7f9b1974fbae61.

\section{Results Regarding the Social Functions of Urban Green Spaces in Lodz}

In this section, we present maps showing the synthesised results for the five main sociotope categories, shown in Figures 1-5. The detailed map showing each sociotope function is available on the InterSIT web page indicated in Section 4.5, while the shapefiles with the mapped sociotope attributes are available as Supplementary Material accompanying the present article.

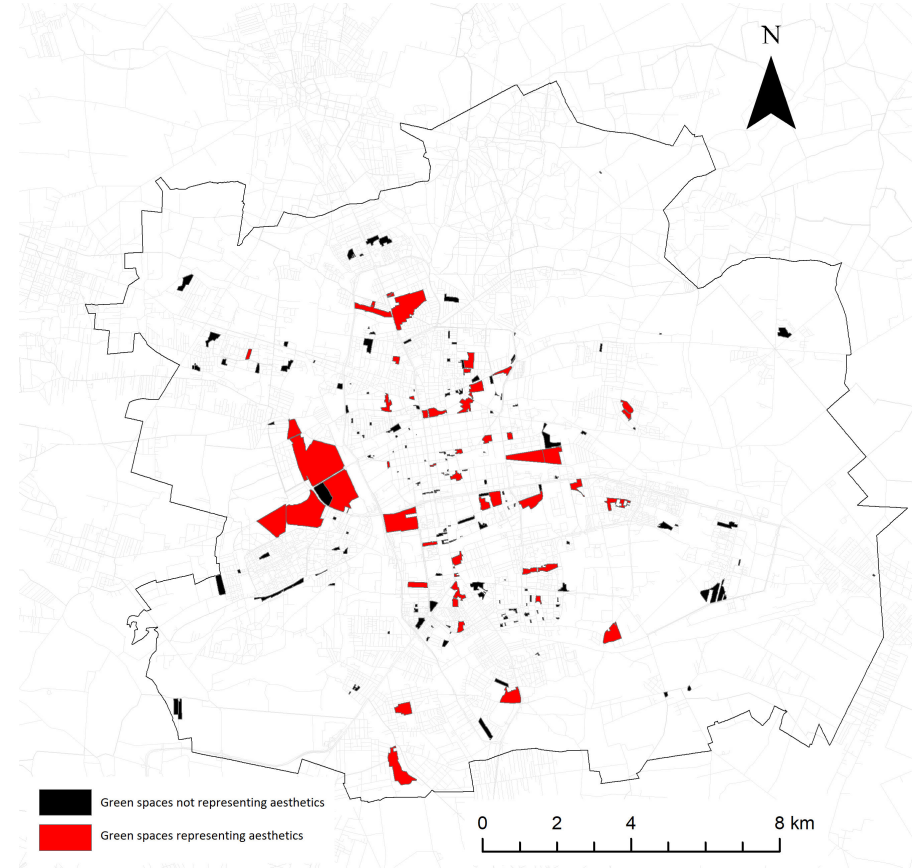

Figure 1. Urban green spaces in Lodz representing the "aesthetics" sociotope category. 


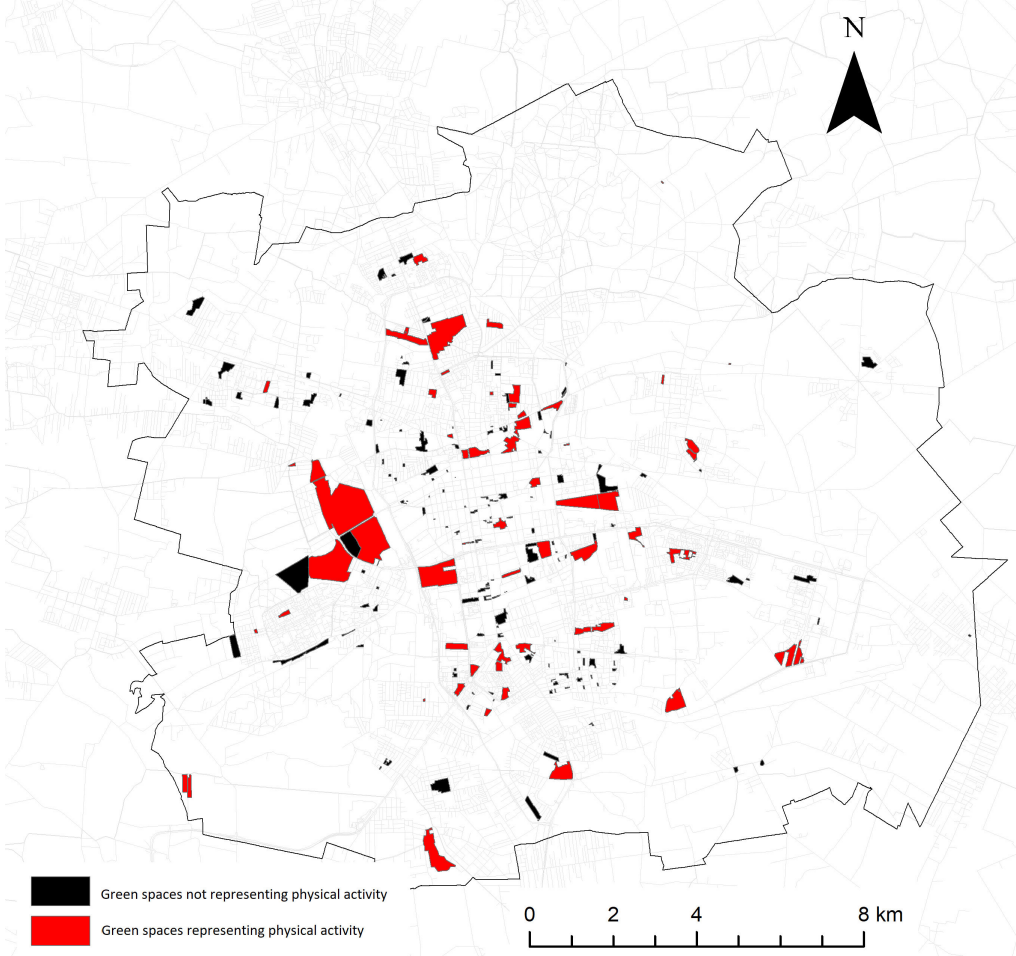

Figure 2. Urban green spaces in Lodz representing the "physical activity" sociotope category.

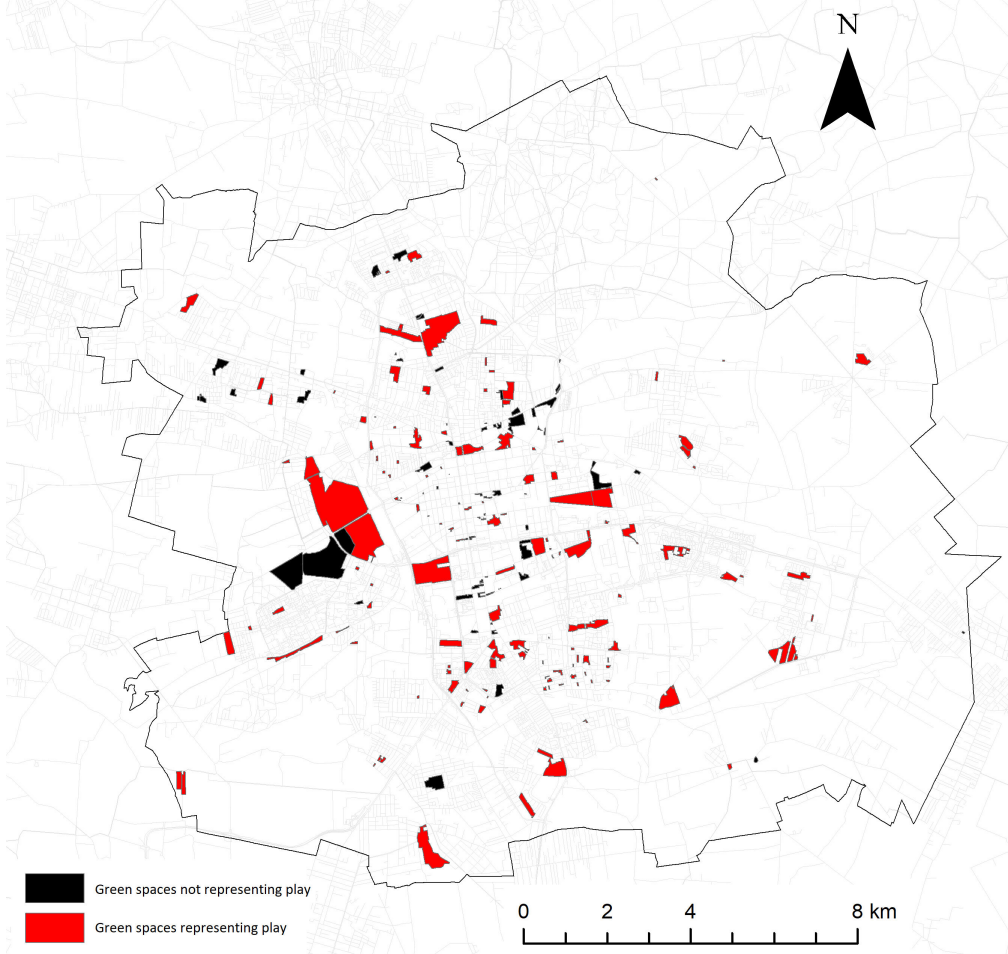

Figure 3. Urban green spaces in Lodz representing the "play" sociotope category. 


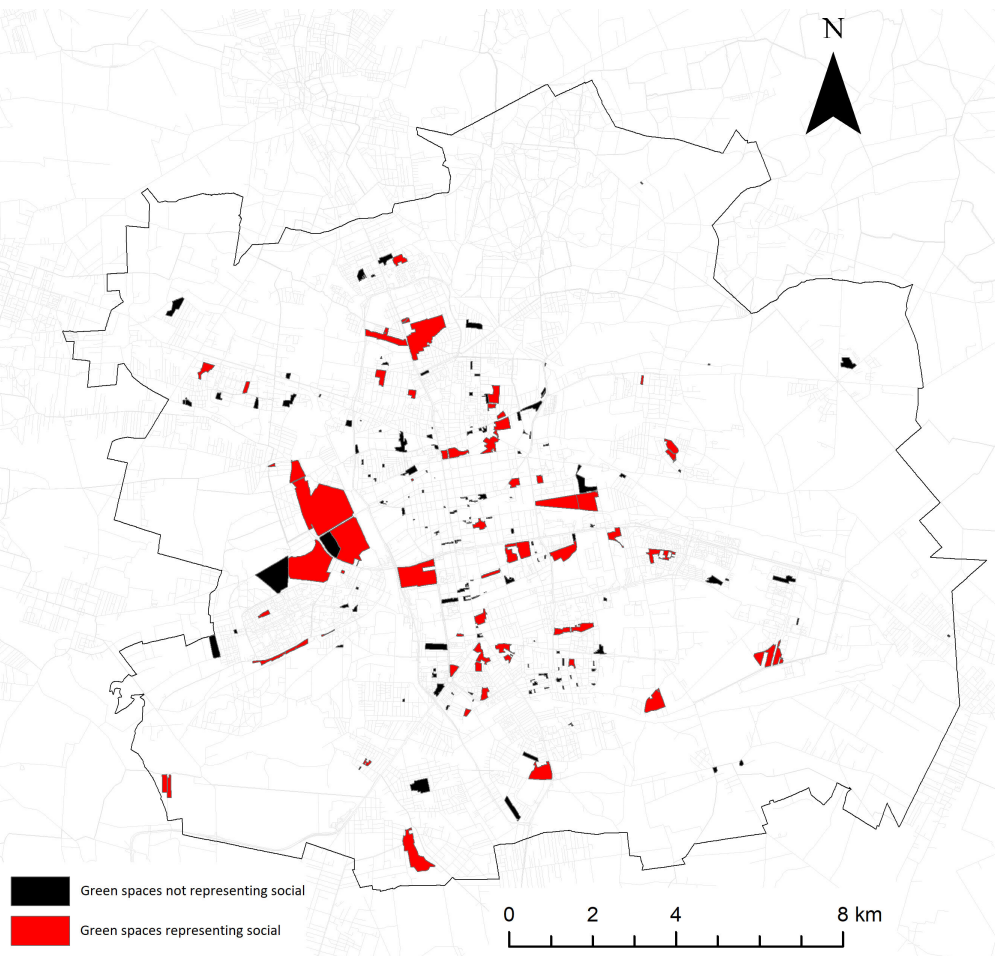

Figure 4. Urban green spaces in Lodz representing the "social" sociotope category.

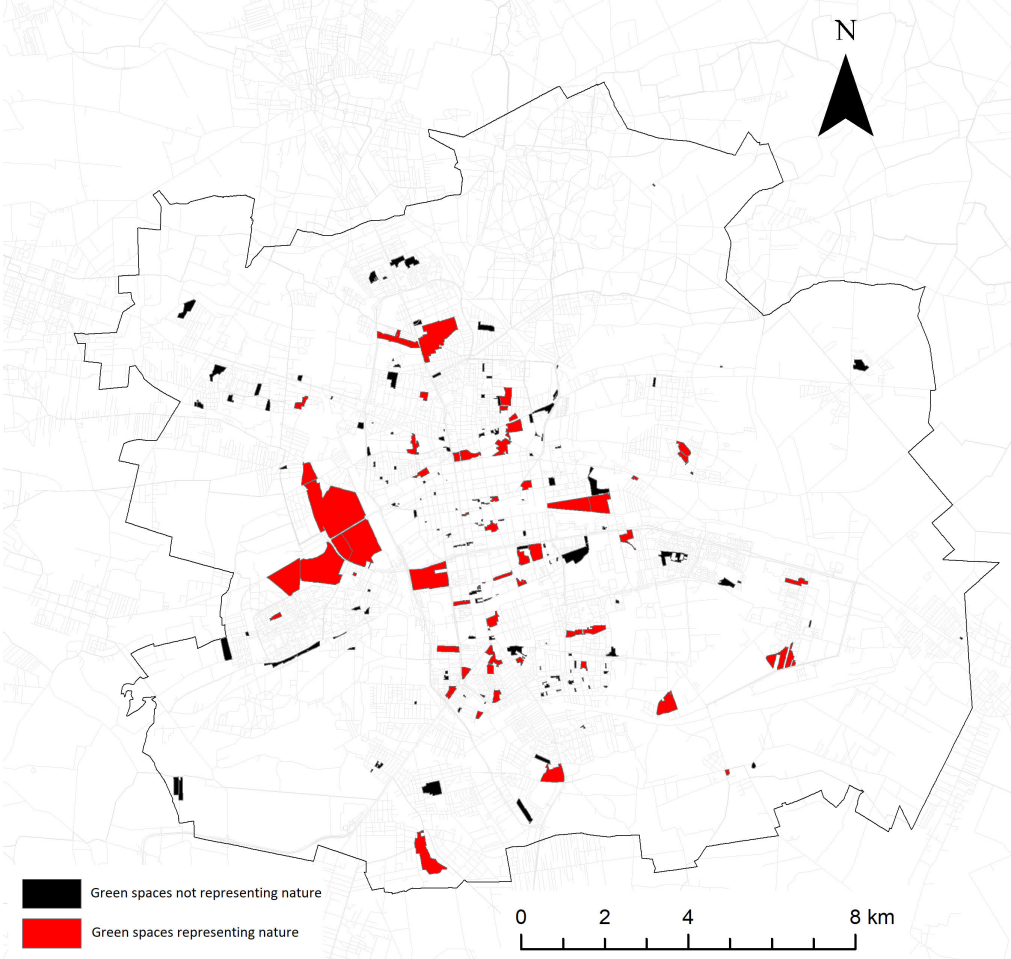

Figure 5. Urban green spaces in Lodz representing the "nature" sociotope category.

\subsection{General Findings}

The full list of sociotope attributes with the number of urban green spaces where these attributes appear can be found in the Appendix A. The parks (along with green squares) and recreational sites differ in the most frequent sociotope attributes. The parks and green squares are most frequently equipped with paths for night walks (96 out of 115 parks and green squares), playgrounds for 
children (50), outdoor gyms (37), flowerbeds (34), toilets (34), chess tables (30), bicycle paths (29), sculptures and monuments (27), and sports fields (26). Additionally, 38 are characterised by their greenness. When it comes to recreational sites, playgrounds for children represent the most popular amenities (75 out of 81 recreational sites), followed by paths for night walks (31). The share of recreational sites equipped with playgrounds is higher than the analogous share for parks and green squares because many of them are established specifically to offer this amenity. Conversely, flowerbeds, toilets, bicycle paths, and sculptures-popular in parks-do not appear in any recreational sites.

We found that 18 sociotope attributes appear in at least 15 parks and green squares, while only three sociotope attributes are listed in at least 15 recreational sites. This may mean that the size of a green space is one of the factors which influences the variety of social functions offered by a given green space. We checked if the area of a park or green square (due to their uniqueness, we eliminated recreational sites from this test) is correlated with the number of different functions listed in such an urban green space. Indeed, the Pearson's correlation equal to 0.3 signifies that the bigger the green space, the more social functions it offers.

\subsection{Maps Showing the Main Sociotope Categories}

According to our results, the number of parks and green squares that represent each sociotope category was similar and varied from 41 for "physical activity" to 57 for "play" (from a total of 115). The situation differed when it came to recreational sites. None of them represented "aesthetics", only three had "social" functions, and two had "nature" functions. From the total of 81 recreational sites, 10 represented "physical activity", 76 represented "play", and 2 represented "nature". Interestingly, 5 recreational sites and 33 parks and green squares could not be assigned to any of the main sociotope categories as they did not have enough sociotope attributes located in their area. On the other hand, 20 parks and green squares were classified as having all five main sociotope functions, and these were the largest parks in Lodz.

In Lodz, 44 parks and green squares had at least two attributes belonging to "aesthetics", hence they could represent this category, shown in Figure 1. The most popular "aesthetics" attributes were: flowerbeds, sculptures, monuments, and the feeling of silence. None of the "aesthetics" attributes appeared in recreational sites.

In Lodz, 41 parks and green squares and 10 recreational sites represented "physical activity", with at least two different attributes belonging to this category, shown in Figure 2. The most popular attributes representing "physical activity" were: outdoor gyms, bicycle paths, sports fields (football, basketball, volleyball, etc.), as well as tennis courts and table tennis tables.

Although the "play" function was assigned to the highest number of parks and green squares (57 out of 115, and 76 recreational sites out of 81), 111 of them only had one sociotope attribute from this category, shown in Figure 3. The most common were playgrounds for children (present in 50 parks and green squares, and 76 recreational sites). Sledging infrastructure (e.g., an artificial hill) was another popular attribute in this category.

Forty-nine parks and green squares represented the "social" category (with at least two attributes), as shown in Figure 4, with the following most common attributes: paths for night walks (equipped with lamp posts) and chess tables. At the opposite end of the scale, only one or two parks were equipped with graduation towers and baby changing facilities.

Forty-eight parks and green squares and two recreational sites represented "nature", as shown in Figure 5. The most frequent attribute was greenness—as assessed by the softGIS respondents-which was characteristic of 38 urban green spaces. Other attributes, such as wildness or sounds of nature, characterised only a few parks and green squares (five and three parks, respectively). 


\section{Discussion}

\subsection{The Usefulness of Sociotope Mapping}

Our study fits into the general trend of using multiple sources of data for urban green space planning and management. Sociotope mapping provides an example of such an approach, which combines official data from municipal records with additional data on inhabitants' preferences or social values attached to urban, green, and public spaces. For our study, we not only combined datasets that represented these two groups, but we also compiled and digitised a large amount of data which were previously stored in paper format only. Although the data we collected and digitised pertained to public spaces, until now, these data were not publicly available. Such information may be useful for researchers and urban inhabitants, the users of the green spaces we described, but also for urban planners and the authorities in Lodz. In many countries, and post- socialist countries in particular, if they do it at all, local authorities in their planning documents set simple targets regarding urban green space availability, but not necessarily attractiveness [34]. Our dataset (similar to other maps of the social functions of green spaces in other cities) offers opportunities to manage green space attractiveness more effectively.

In the present discussion, we refer to how the map and the underlying dataset could potentially be used in urban green space planning and management, and why it has not been used in real life (at least as of yet). We also argue that the data we provide offers opportunities for many other uses, beyond formal applications by the local authorities. The dataset is far more comprehensive than any other dataset compiled so far for urban green spaces in Lodz, as discussed in the following subsection, which, at the very least, offers multiple opportunities for use by other researchers, as discussed in Section 6.3. Nevertheless, let us start with the local authorities.

The dataset could potentially be of use to the local authorities, and indeed they did express an interest in creating a sociotope map for urban green spaces in Lodz when we approached them. As discussed in the initial meetings, the map could help to overcome barriers that prevent successful management, such as insufficient information [1] and the sector silos, or even lack of collaboration between different actors involved in urban green space management, even within the same units or institutions [7,8].

However, as time went by, as in the case of many similar endeavours, the initial enthusiasm seemed to evaporated, and new doubts emerged. One potential problem was that the respective authorities did not really see how they could use the map. Having a map-and the underlying data readily available-is one thing, but being able to use it is another. Public authorities in Poland often lack the technical skills, equipment, or software and management systems that would benefit from a sociotope map [1]. The employees may even feel comfortable in the existing system, where one person is responsible for a given park, or at least for a given scope of the park's social functions, with all the data safely stored in files kept on shelves rather than in a computer, and with a clear division of responsibilities and a safe operating space for each individual. The authorities may not necessarily imagine (or want to imagine) how the goals and duties of their units could be facilitated by the new dataset and the digital opportunities that it brings about. The above indicates a path dependence problem. Additionally, to be useful, the dataset needs to be updated, and with dispersed responsibility for urban green spaces in Lodz, there is no single unit interested in taking on the task of updating and managing the whole dataset.

The Polish central statistical office-Statistics Poland-collects information on quality of life indicators, such as "satisfaction with recreational and green spaces", "exposure to excessive noise levels", and "exposure to pollution and other local environmental problems" [35]. These indicators are based on subjective opinions expressed in pan-European surveys. In our opinion, the responses to these questions may be partly related to the citizens' awareness of what green spaces offer; hence, if the local authorities were to more actively participate in promoting green space use (and share 
the information regarding what they offer) among the inhabitants, they could potentially positively influence such indicators.

Interestingly, in general, green spaces are increasingly used for city branding and other city marketing purposes, with cities competing against each other for the preferred inhabitants [36]. This trend is also emerging in Poland, and Lodz seems to be one of the leading examples, with a previous-failed - attempt to obtain the European Green Capital Award [37]. It can currently boast that it has been chosen to organise the International Horticultural Exhibition 2024, with a focus on "Nature in the City". The Exhibition would affect a complex of three neighbouring parks in Lodz, allegedly increasing these parks' attractiveness. However, the nearby inhabitants have not been consulted on the decisions, and it seems that the exhibition would likely to lead to the gentrification of these parks, by furnishing them with cafes, galleries, and exposition spaces, but not necessarily addressing other social functions highlighted as relevant in our study. The exhibition could also provide an excellent opportunity to attract the inhabitants and tourists to other green spaces in Lodz, and our map-especially if developed into a mobile app and updated—would fit this objective perfectly.

The above example of the Horticultural Exhibition being organised in a complex of three neighbouring parks in Lodz illustrates another aspect of sociotope mapping. In Stockholm, it was originally meant to be supplementary to biotope mapping, indicating the dominant ecological importance of urban green spaces. The exhibition neglects ecological and biological aspects and entirely focuses on social ones. Our map indicates some ecological functions, but they are necessarily dwarfed by the social ones, which is as if we had started the whole process of mapping the green spaces from the reverse. Meanwhile, in general, the ecological functions of green spaces in Lodz have not attracted enough attention yet, and any attempts to use them for broader purposes, such as nature-based solutions, seem to have brought little success so far [38,39]. It is absolutely vital to create a map of the biological and ecological functions of urban green spaces in Lodz and to create an active system of urban green space management based on a digital green space inventory.

As indicated above, our map and the whole process behind its preparation illustrate broader challenges related to urban green space management in Lodz, or post-socialist cities in general $[40,41]$. Additionally, the process of promoting the sociotope map for Lodz illustrates broader challenges related to the acknowledgement of place values that are revealed through various methods of mapping the social functions of green spaces in land-use decisions [42]. The key problem seems to be that the initiative emerged on the part of researchers, and the local authorities seem to have been reluctant to take the initiative further. In an ideal situation, the authorities would come up with an idea and then ask researchers and other external experts to support the idea, and not the other way around, as in our case. In an ideal world, the authorities would actively promote the map and use it for communication with the inhabitants, while in our case, seven months passed from when the map was available on the official GIS site of Lodz to it being linked by the Urban Green Space Authority on its website. The only promotional materials that went out were through our university's official press releases. In an ideal world, the authorities should actively use the map, while in our case, the map has not been used for official purposes in any other form, apart from being posted on the Authority's website. Clearly, the authorities responsible for urban green space management have other, more pressing needs and act on limited budgets, which translates into numerous inefficiencies and institutional failures [40]. Meanwhile, although we do see the potential use for the map for research purposes, as explained in Section 6.3, we were also hoping that the authorities would take up this work. Indeed, multiple examples are available from various cities where different local stakeholders' inputs are carefully integrated into local green space planning and management, spanning far beyond the already highlighted case of Stockholm [43-47].

\subsection{Increased Availability of Information on the Attractiveness of Urban Green Spaces in Lodz}

Despite the problems discussed above, the largest effort involved in this study (i.e., to collect data from different sources), would not have been possible without the openness to collaboration on the 
part of the relevant stakeholders-the owners of the data. The data had not been stored in digital format and - even within the different organisations- the data had not been stored in a single file. Quite the opposite; the data had been dispersed, and only the individual employees responsible for the different aspects of green space management or maintenance kept them in their own paper files. Hence, what we obtained was a completely new and comprehensive dataset regarding formal urban green spaces in Lodz, which can be used further in research, planning, communication, and maintenance.

The analysed data indicated the numerous social functions available in formal urban green spaces in Lodz, many of which seem not to be known to the general public. For the time being, the information is up-to-date and comprehensive, and it represents a useful update and complement to other sources of information on formal green spaces in Lodz. Indeed, our study is far more comprehensive than any study carried out so far in Lodz, in terms of the number of green spaces covered and the breadth of the functions included.

So far, the attractiveness of urban green spaces in Lodz has been explicitly addressed principally through the lens of barriers that prevent attractiveness, with a focus on the lack of park infrastructure or factors such as air pollution and other nuisances $[3,4,48]$. The attractiveness of urban green spaces in Lodz was also investigated through the lens of user perceptions with the use of participatory GIS [12], the results of which, as explained in Section 3.2.3, were partly incorporated into our map as well. Other relevant publications focused on historical parks in the city centre and investigated their attractiveness from the point of view of historical and natural features [49-53], or they provided a broader and yet still selective overview of the parks in Lodz [54] and in the region of Lodz [55]. Most of these studies focused on a historical description of the respective parks, and the historical and natural monuments which could be found in them. As such, they can serve as good sources of detailed information for local inhabitants, but they lack a broader overview of the modern functions of the described parks. Yet other publications focus on the selected features of parks in Lodz, such as fountains [56,57] or water bodies [58]. These studies necessarily focus on those parks where such amenities are available. Eventually, one can also find more specific information on urban green spaces in Lodz in specialised publications, such as a bird atlas that indicates which species of bird nest in which parks in Lodz [59].

The functions of the 42 parks in Lodz (altogether 54 parks in the whole metropolitan region) were thoroughly analysed and discussed by Durecka [60], who investigated not only their genesis and original functions, but also their modern attractiveness based on what they offer. Although the author inventoried many functions based on publicly available datasets, she only provided descriptive information and tables; hence, the information remained difficult to access for other researchers. Durecka's [60] inventories resulted in park typologies for the Lodz metropolitan region, which included parks that were divided based on both natural and cultural features. Although our study is more comprehensive and based on more thorough evidence, it largely confirms the results of the park comparisons performed by Durecka [60].

The functions offered by parks in Lodz and the inhabitants' willingness to benefit from them were also studied by Olbińska [61]. The dominant activities in parks in Lodz, identified by Olbińska [61], were walking, resting on a bench, walking the dog, observing nature, running, meeting with friends, riding a bicycle, and playing with children, but our map provides a much more nuanced picture, which can be useful, in particular, for more specialist users interested in relatively less popular activities. Olbińska [61] suggested that the lower frequency of practising sports may be related to the lack of adequate sites and facilities; however, in our opinion, it may result from the lack of information on the availability of such sites and facilities. This is where our map might prove particularly useful.

\subsection{Further Research}

We add new geographically explicit information which can be used by urban planners and inhabitants interested in what parks and other green spaces in Lodz offer in terms of recreational and cultural potential, but which can also be used in further analyses of urban green spaces in Lodz. 
For example, our map might add new information to studies, such as hedonic pricing, which is often used to capture the monetary value of urban green spaces of different types, adding new specific features of green spaces that might potentially affect the value of nearby real estate, on top of what has already been studied in this city so far [62-65]. Such a study is already available for Stockholm where it turned out that urban green spaces which offer more social functions (based on the sociotope map) had a greater positive influence on the prices of nearby properties [66]. Another example of the use of the sociotope map from Stockholm was in a study on social-ecological networks in the city, where the sociotope map was combined with a number of other sources of data [67].

Similarly, new information collected in a sociotope map could be used in studies that focus on environmental justice, indicating which functions or attributes are available to which groups of potential users (e.g., divided based on their socioeconomic status (cf. [68]), or in simpler studies on the general accessibility to such functions or attributes $[69,70])$. Indeed, this would be in line with so-called equity mapping, which indicates which types of green spaces are available, accessible, or attractive to different socioeconomic groups, with a particular focus on the vulnerable ones [71,72]. Finally, any comparative study on urban green spaces in Lodz could benefit from our dataset, including those on the distribution of park functions, which so far have had to rely on diverse and dispersed sources of data (cf. [60]). To facilitate further use, we provide the full dataset as Supplementary Material accompanying the present article. In this way, we attempt to counteract a trend that is prevalent in Polish cities, that data are often there, but not available to those who need them $[7,8]$. This requires further programming and research effort.

Once the map is generated, it is possible to proceed with further analyses of the sociotopes themselves. We calculated Pearson's correlation between green space size and the number of sociotope functions listed in a given green space, as detailed in Section 5.1. However, one could also try to find out more analytically which sociotope attributes occur together, and which green space characteristics (other than size) influence these attributes (such as location, nearby infrastructures, and types of vegetation). Indeed, these issues go beyond our present study but do offer interesting avenues for further research.

Future research—both in Lodz and in other cities undertaking similar initiatives—should involve not only formal public spaces but also informal ones, such as vacant lots, railway surroundings, arable land and orchards, private gardens, and many others. Such informal green spaces are often used for recreational purposes, but they are not managed and maintained for these purposes, and they are typically not managed by public institutions. Indeed, informal green spaces often account for a large share of the total urban green space, which is also the case in Lodz, where they may represent up to approximately $85 \%$ of the total green area $[1,17]$. The lack of consideration of informal green spaces may be seen as a limitation of the present study, but also as an important opportunity for further research.

The digital and spatially explicit format of the collected information is also new, along with its public availability. Inhabitants and tourists preparing for a visit to Lodz can easily find information and plan for their time in urban green spaces in Lodz. Still, the current format of this dataset may prevent some potential uses, primarily because it does not display well on smartphones. A new smartphone-dedicated version of the map would be particularly useful to spread the information even further, to facilitate the use of urban green spaces in Lodz, and to potentially even to attract new users to these spaces. Only then, by making information on urban green space attractiveness easily available, would this map really break the informational barriers that prevent urban green space accessibility in Lodz [3].

Finally, while comparisons between cities are of limited use (Lodz is very different to Stockholm, and green spaces, their functions, as well as their management quality in each city are different), it would be highly relevant to update the map and compare the different versions produced in the same city over time. An updated map would ensure its continued usefulness for researchers, inhabitants, and planners alike. This has been the case in Stockholm, where sociotope mapping has become one 
of the tools used in urban planning; however, it is less likely to enter the mainstream in Lodz or other Polish cities. This is related to the broader challenges which prevent successful green space management in Polish cities, as discussed in Section 6.1.

\section{Conclusions}

To counteract the problem of scattered and fragmented data on urban green spaces in Lodz, we created a sociotope map by eliciting and bringing together various sources of information. We worked together with several local stakeholders who owned the different sections of the data, and sought additional information from external sources, including a previous study on inhabitants' perceptions. Linking the multiple sources of data was facilitated by geocoding and digitising the information, much of which had previously only been stored in dispersed paper files. The digital and geographical formats of the data make it available for many further uses, and it should support the management and maintenance of the urban green spaces in the city. However, the future usefulness of our map depends on whether the local authorities take the initiative to update and use the map for, among other things, communicating with the inhabitants. This, however, requires overcoming multiple institutional barriers and failures related to urban green space management in Polish cities.

Supplementary Materials: The following are available online at http://www.mdpi.com/2073-445X/9/6/183/s1. The shapefiles with the mapped sociotope attributes, divided into parks and green squares and recreational sites, with the description of the data structure, are available in zipped files.

Author Contributions: E.Ł.: Conceptualization, Methodology, Validation, Software, Formal Analysis, Investigation, Data Curation, Writing-Original Draft Preparation, Writing-Review and Editing, Visualization, and Supervision; P.C.: Conceptualization, Validation, Software, Formal Analysis, Investigation, Data Curation, and Visualization; J.K.: Conceptualization, Methodology, Validation, Formal Analysis, Investigation, Writing-Original Draft Preparation, Writing-Review and Editing, Supervision, Funding Acquisition, and Project Administration. All authors have read and agreed to the published version of the manuscript.

Funding: This research was funded through the 2015-2016 BiodivERsA COFUND call for research proposals, by the national funders: the Swedish Research Council for Environment, Agricultural Sciences, and Spatial Planning, the Swedish Environmental Protection Agency, the German Aeronautics and Space Research Centre, the National Science Centre (Poland) (grant no. 2016/22/Z/NZ8/00003), the Research Council of Norway, and the Spanish Ministry of Economy and Competitiveness.

Acknowledgments: We would like to thank Magdalena Biernacka for her technical assistance with geocoding and mapping some of the data. We would like to thank the representatives of the Urban Green Space Authority (ZZM), the Department of Municipal Management (WGK) in the City Office of Lodz, the Municipal Sports and Recreation Center (MOSiR), the City Centre of Geodesy (LOG), the Municipal Planning Office (MPU), and the National Institute of Heritage for providing the data and for creative discussions that eventually led to the preparation of the sociotope map for Lodz.

Conflicts of Interest: The authors declare no conflict of interest. The funders had no role in the design of the study, in the collection, analyses, or interpretation of data, in the writing of the manuscript, or in the decision to publish the results.

\section{Appendix A}

Table A1. The number of urban green spaces where a given attribute is located.

\begin{tabular}{ccc}
\hline Attribute & $\begin{array}{c}\text { Number of Parks and } \\
\text { Green Squares }\end{array}$ & Number of Recreational Sites \\
\hline Archaeological objects & 1 & 0 \\
\hline Flowerbeds & 34 & 0 \\
\hline Fountains & 13 & 0 \\
\hline $\begin{array}{c}\text { Historic architectural objects } \\
\text { (sculptures, villas, monuments, } \\
\text { remains of cemeteries, workers' } \\
\text { settlements, factories, etc.) }\end{array}$ & 14 & 0 \\
\hline
\end{tabular}


Table A1. Cont.

\begin{tabular}{|c|c|c|}
\hline Attribute & $\begin{array}{l}\text { Number of Parks and } \\
\text { Green Squares }\end{array}$ & Number of Recreational Sites \\
\hline Interesting topographic features & 10 & 0 \\
\hline Sculptures, monuments & 27 & 0 \\
\hline Silence & 25 & 0 \\
\hline Spaciousness, open space & 16 & 0 \\
\hline Uniqueness & 13 & 0 \\
\hline View, landscape & 14 & 0 \\
\hline Water & 20 & 0 \\
\hline Animals & 12 & 0 \\
\hline Greenness & 38 & 2 \\
\hline Nature monuments & 22 & 0 \\
\hline Sounds of nature & 3 & 0 \\
\hline Wildness & 5 & 0 \\
\hline $\begin{array}{l}\text { Other unique objects (e.g., single } \\
\text { places to play table football } \\
\text { and pétanque) }\end{array}$ & 9 & 1 \\
\hline Bicycle stands & 13 & 0 \\
\hline $\begin{array}{l}\text { Stations of the public } \\
\text { bicycle scheme }\end{array}$ & 2 & 0 \\
\hline Bicycle paths & 29 & 0 \\
\hline Indoor pools & 3 & 0 \\
\hline Outdoor gyms & 37 & 17 \\
\hline Paths for runners & 15 & 0 \\
\hline Table tennis tables & 22 & 10 \\
\hline $\begin{array}{l}\text { Sports fields (football, basketball, } \\
\text { volleyball, etc.), tennis courts }\end{array}$ & 26 & 12 \\
\hline Ice rinks & 0 & 0 \\
\hline Routes for cross-country skiing & 2 & 0 \\
\hline Sports events & 5 & 0 \\
\hline $\begin{array}{l}\text { Water equipment rental } \\
\text { (pedalos, kayaks, etc.) }\end{array}$ & 3 & 0 \\
\hline $\begin{array}{l}\text { Amusement parks } \\
\text { (recreation areas) }\end{array}$ & 5 & 0 \\
\hline $\begin{array}{l}\text { Natural playgrounds (including } \\
\text { rope courses, parks with wooden } \\
\text { infrastructure, etc.) }\end{array}$ & 3 & 0 \\
\hline Outdoor swimming & 5 & 0 \\
\hline Playgrounds for children & 50 & 75 \\
\hline Pump tracks & 3 & 0 \\
\hline Skateparks & 1 & 2 \\
\hline $\begin{array}{l}\text { Sledging infrastructure (e.g. } \\
\text { artificial hills) }\end{array}$ & 20 & 1 \\
\hline
\end{tabular}


Table A1. Cont.

\begin{tabular}{ccc}
\hline Attribute & $\begin{array}{c}\text { Number of Parks and } \\
\text { Green Squares }\end{array}$ & Number of Recreational Sites \\
\hline $\begin{array}{c}\text { The possibility of practising } \\
\text { water sports }\end{array}$ & 3 & 0 \\
\hline $\begin{array}{c}\text { Amphitheatres, bowers, } \\
\text { art galleries }\end{array}$ & 12 & 0 \\
\hline BBQ spots & 11 & 0 \\
\hline $\begin{array}{c}\text { Cafes, other catering facilities } \\
\text { (all-year-round) }\end{array}$ & 6 & 0 \\
\hline Baby changing facilities & 2 & 0 \\
\hline Chess tables & 30 & 9 \\
\hline Dog-friendliness & 2 & 0 \\
\hline $\begin{array}{c}\text { Entertainment events, } \\
\text { concerts, etc. }\end{array}$ & 4 & 0 \\
\hline Graduation towers & 1 & 0 \\
\hline $\begin{array}{c}\text { Mobile gastronomy (e.g., food } \\
\text { trucks, coffee bikes) }\end{array}$ & 9 & 31 \\
\hline $\begin{array}{c}\text { Paths for night walks (equipped } \\
\text { with lamp posts) }\end{array}$ & 96 & 0 \\
\hline Toilets & 34 & 0 \\
\hline
\end{tabular}

\section{References}

1. Feltynowski, M.; Kronenberg, J.; Bergier, T.; Kabisch, N.; Łaszkiewicz, E.; Strohbach, M. Challenges of urban green space management in the face of using inadequate data. Urban For. Urban Green. 2018, 31, 56-66. [CrossRef]

2. Pauleit, S.; Ambrose-Oji, B.; Andersson, E.; Anton, B.; Buijs, A.; Haase, D.; Elands, B.; Hansen, R.; Kowarik, I.; Kronenberg, J.; et al. Advancing urban green infrastructure in Europe: Outcomes and reflections from the GREEN SURGE project. Urban For. Urban Green. 2019, 40, 4-16. [CrossRef]

3. Biernacka, M.; Kronenberg, J. Classification of institutional barriers affecting the availability, accessibility and attractiveness of urban green spaces. Urban For. Urban Green. 2018, 36, 22-33. [CrossRef]

4. Biernacka, M.; Kronenberg, J.; Łaszkiewicz, E. An integrated system of monitoring the availability, accessibility and attractiveness of urban parks and green squares. Appl. Geogr. 2020, 116, 102152. [CrossRef]

5. Ngom, R.; Gosselin, P.; Blais, C. Reduction of disparities in access to green spaces: Their geographic insertion and recreational functions matter. Appl. Geogr. 2016, 66, 35-51. [CrossRef]

6. Dragićević, S.; Balram, S. A Web GIS collaborative framework to structure and manage distributed planning processes. J. Geogr. Syst. 2004, 6, 133-153. [CrossRef]

7. Kronenberg, J.; Pietrzyk-Kaszyńska, A.; Zbieg, A.; Żak, B. Wasting collaboration potential: A study in urban green space governance in a post-transition country. Environ. Sci. Policy 2016, 62, 69-78. [CrossRef]

8. Mabelis, A.A.; Maksymiuk, G. Public participation in green urban policy: Two strategies compared. Int. J. Biodivers. Sci. Manag. 2009, 5, 63-75. [CrossRef]

9. Hamstead, Z.A.; Fisher, D.; Ilieva, R.T.; Wood, S.A.; McPhearson, T.; Kremer, P. Geolocated social media as a rapid indicator of park visitation and equitable park access. Comput. Environ. Urban Syst. 2018, 72, 38-50. [CrossRef]

10. Langemeyer, J.; Calcagni, F.; Baró, F. Mapping the intangible: Using geolocated social media data to examine landscape aesthetics. Land Use Policy 2018, 77, 542-552. [CrossRef]

11. Lopez, B.E.; Magliocca, N.R.; Crooks, A.T. Challenges and opportunities of social media data for socio-environmental systems research. Land 2019, 8, 107. [CrossRef] 
12. Pietrzyk-Kaszyńska, A.; Czepkiewicz, M.; Kronenberg, J. Eliciting non-monetary values of formal and informal urban green spaces using public participation GIS. Landsc. Urban Plan. 2017, 160, 85-95. [CrossRef]

13. Rall, E.; Hansen, R.; Pauleit, S. The added value of public participation GIS (PPGIS) for urban green infrastructure planning. Urban For. Urban Green. 2019, 40, 264-274. [CrossRef]

14. Baker, F.; Smith, C.L.; Cavan, G. A Combined Approach to Classifying Land Surface Cover of Urban Domestic Gardens Using Citizen Science Data and High Resolution Image Analysis. Remote Sens. 2018, 10, 537. [CrossRef]

15. Dennis, M.; Barlow, D.; Cavan, G.; Cook, P.A.; Gilchrist, A.; Handley, J.; James, P.; Thompson, J.; Tzoulas, K.; Wheater, C.P.; et al. Mapping Urban Green Infrastructure: A Novel Landscape-Based Approach to Incorporating Land Use and Land Cover in the Mapping of Human-Dominated Systems. Land 2018, 7, 17. [CrossRef]

16. Lahoti, S.; Kefi, M.; Lahoti, A.; Saito, O. Mapping Methodology of Public Urban Green Spaces Using GIS: An Example of Nagpur City, India. Sustainability 2019, 11, 2166. [CrossRef]

17. Sikorska, D.; Łaszkiewicz, E.; Krauze, K.; Sikorski, P. The role of informal green spaces in reducing inequalities in urban green space availability to children and seniors. Environ. Sci. Policy 2020, 108, 144-154. [CrossRef]

18. Babelon, I.; Ståhle, A.; Balfors, B. Toward Cyborg PPGIS: Exploring socio-technical requirements for the use of web-based PPGIS in two municipal planning cases, Stockholm region, Sweden. J. Environ. Plan. Manag. 2017, 60, 1366-1390. [CrossRef]

19. Ståhle, A. Sociotope mapping: Exploring public open space and its multiple use values in urban and landscape planning practice. Nord. J. Archit. Res. 2006, 19, 59-71.

20. Lindholst, A.C.; Caspersen, O.H.; Konijnendijk van den Bosch, C.C. Methods for mapping recreational and social values in urban green spaces in the Nordic countries and their comparative merits for urban planning. J. Outdoor Recreat. Tour. 2015, 12, 71-81. [CrossRef]

21. Nordh, H. Park Characteristics: A Tool for Classifying and Designing Urban Green Spaces; VDM Verlag: Saarbrücken, Germany, 2010.

22. Lindholst, A.C.; Dempsey, N.; Burton, M. Introducing a method for mapping recreational experience. Proc. Inst. Civ. Eng. Urban Des. Plan. 2013, 166, 296-308. [CrossRef]

23. Tyrväinen, L.; Mäkinen, K.; Schipperijn, J. Tools for mapping social values of urban woodlands and other green areas. Landsc. Urban Plan. 2007, 79, 5-19. [CrossRef]

24. Massoni, E.S.; Barton, D.N.; Rusch, G.M.; Gundersen, V. Bigger, more diverse and better? Mapping structural diversity and its recreational value in urban green spaces. Ecosyst. Serv. 2018, 31, 502-516. [CrossRef]

25. Hanzl, M.; Dzik, K.; Kowalczyk, P.; Kwieciński, K.; Stankiewicz, E.; Wierzbicka, A.Ł. Human geomatics in urban design-Two case studies. Future Internet 2012, 4, 347-361. [CrossRef]

26. Andersson, E.; Langemeyer, J.; Borgström, S.; McPhearson, T.; Haase, D.; Kronenberg, J.; Barton, D.N.; Davis, M.; Naumann, S.; Röschel, L.; et al. Enabling green and blue infrastructure to improve contributions to human well-being and equity in urban systems. BioScience 2019, 69, 566-574. [CrossRef]

27. Kaczynski, A.T.; Schipperijn, J.; Hipp, J.A.; Besenyi, G.M.; Wilhelm Stanis, S.A.; Hughey, S.M.; Wilcox, S. ParkIndex: Development of a standardized metric of park access for research and planning. Prev. Med. 2016, 87, 110-114. [CrossRef]

28. Collin, P.H. Dictionary of Environment and Ecology, 5th ed.; Bloomsbury: New York, NY, USA, 2004.

29. Ask, E. To Map Social Values in the Outdoor Environment of the City. Sociotope Mapping as a Method in Stockholm and Goteborg; Swedish University of Agricultural Sciences: Alnarp, Sweden, 2013. (In Swedish)

30. Hedman, K. Sociotope Mapping in a Smaller Village-A Study in Östervåla. 2010; (In Swedish). Available online: https://stud.epsilon.slu.se/1114/1/hedman_k_100429.pdf (accessed on 12 February 2020).

31. Kungsbacka Municipality Sociotopkarta. Kungsbacka Stad. Sammanställning av Observationer, Intervjuer Och Enkätundersökning. 2016; (In Swedish). Available online: https://docplayer.se/35013339-Sociotopkartakungsbacka-stad-sammanstallning-av-observationer-intervjuer-och-enkatundersokning-april-2016.html (accessed on 20 March 2020).

32. Nordström, M.; Sandberg, A.; Ståhle, A. The Sociotop Guide-Planning Public Open Space with Stockholmers and the Sociotop Map; Stadsbyggnadskontoret: Stockholm, Sweden, 2003. (In Swedish)

33. Dzionek-Kozlowska, J.; Kowalski, K.; Matera, R. The effect of geography and institutions on economic development: The case of Lodz. J. Interdiscip. Hist. 2018, 48, 523-538. [CrossRef] 
34. Niță, M.-R.; Anghel, A.-M.; Bănescu, C.; Munteanu, A.-M.; Pesamosca, S.-S.; Zețu, M.; Popa, A.-M. Are Romanian urban strategies planning for green? Eur. Plan. Stud. 2018, 26, 158-173. [CrossRef]

35. GUS Jakość życia w Polsce; Główny Urząd Statystyczny: Warszawa, Poland, 2017.

36. Andersson, E.; Kronenberg, J.; Haase, D.; Adams, C. (Eds.) Cash Flows Generated by Urban Green Spaces: Methods for Identifying Indirect Values of UGI; Report of the GREEN SURGE Project (Deliverable 4.2); Department of Geosciences and Natural Resource Management, University of Copenhagen: Copenhagen, Denmark, 2015.

37. Baltina, O.; Burszta-Adamiak, E.; Cai, H.; Dedova, M.; Dziankowska, J.; Gust, A.; Huskowska, A.; Imre, B.; Istrate, A.; Janiak, K.; et al. Lodz as European Green Capital by 2020; Sendzimir Foundation: Lodz, Poland, 2011.

38. Kronenberg, J.; Bergier, T.; Maliszewska, K. The challenge of innovation diffusion: Nature-based solutions in Poland. In Nature-Based Solutions to Climate Change Adaptation in Urban Areas: Theory and Practice of Urban Sustainability Transitions; Kabisch, N., Korn, H., Stadler, J., Bonn, A., Eds.; Springer: Berlin, Germany, 2017; pp. 291-305.

39. Kronenberg, J.; Krauze, K.; Wagner, I. Focusing on ecosystem services in the multiple social-ecological transitions of Lodz. In Urban Sustainability Transitions; Frantzeskaki, N., Castan Broto, V., Coenen, L., Loorbach, D., Eds.; Routledge: London, UK, 2017; pp. 331-345.

40. Kronenberg, J. Why not to green a city? Institutional barriers to preserving urban ecosystem services. Ecosyst. Serv. 2015, 12, 218-227. [CrossRef]

41. Kronenberg, J.; Haase, A.; Łaszkiewicz, E.; Antal, A.; Baravikova, A.; Biernacka, M.; Dushkova, D.; Filčák, R.; Haase, D.; Ignatieva, M.; et al. Environmental Justice in the Context of Urban Green Space Availability, Accessibility, and Attractiveness in Postsocialist Cities. Available online: https://www.researchgate.net/publication/339719803_Environmental_Justice_in_the_Context_of_ Urban_Green_Space_Availability(accessed on 20 March 2020).

42. Brown, G.; Reed, P.; Raymond, C.M. Mapping place values: 10 lessons from two decades of public participation GIS empirical research. Appl. Geogr. 2020, 102156. [CrossRef]

43. Connolly, J.J.; Svendsen, E.S.; Fisher, D.R.; Campbell, L.K. Organizing urban ecosystem services through environmental stewardship governance in New York City. Landsc. Urban Plan. 2013, 109, 76-84. [CrossRef]

44. Faehnle, M.; Bäcklund, P.; Tyrväinen, L.; Niemelä, J.; Yli-Pelkonen, V. How can residents' experiences inform planning of urban green infrastructure? Case Finland. Landsc. Urban Plan. 2014, 130, 171-183. [CrossRef]

45. Ferreira, V.; Barreira, A.P.; Loures, L.; Antunes, D.; Panagopoulos, T. Stakeholders' Engagement on Nature-Based Solutions: A Systematic Literature Review. Sustainability 2020, 12, 640. [CrossRef]

46. Buijs, A.; Hansen, R.; Van der Jagt, S.; Ambrose-Oji, B.; Elands, B.; Lorance Rall, E.; Mattijssen, T.; Pauleit, S.; Runhaar, H.; Stahl Olafsson, A.; et al. Mosaic governance for urban green infrastructure: Upscaling active citizenship from a local government perspective. Urban For. Urban Green. 2019, 40, 53-62. [CrossRef]

47. Babelon, I. Mapping Place Values for the Green, Compact and Healthy City: Interlinking Softgis, Sociotope Mapping and Communities of Practice. Master's Thesis, KTH, Stockholm, Sweden, 2015.

48. Biernacka, M.; Kronenberg, J. Urban green space availability, accessibility and attractiveness, and the delivery of ecosystem services. Cities Environ. 2019, 12, 5.

49. Olaczek, R. (Ed.) Parki i Ogrody Łodzi: Park im. ks. bp. Michała Klepacza; Stowarzyszenie Film-Przyroda-Kultura: Łódź, Poland, 2014.

50. Olaczek, R. (Ed.) Parki i Ogrody Łodzi: Park Sienkiewicza, Park Moniuszki, Ogrody i Zieleńce w Centrum Miasta; Stowarzyszenie Film-Przyroda-Kultura: Łódź, Poland, 2012.

51. Olaczek, R. (Ed.) Parki i Ogrody Łodzi: Ogrody Nad Łódką; Stowarzyszenie Film-Przyroda-Kultura: Łódź, Poland, 2010.

52. Olaczek, R. (Ed.) Parki i Ogrody Łodzi: Park Źródliska I; Stowarzyszenie Film-Przyroda-Kultura: Łódź, Poland, 2006.

53. Olaczek, R.; Bonisławski, R. (Eds.) Parki i Ogrody Łodzi: Ogrody Księżego Młyna; Stowarzyszenie Film-Przyroda-Kultura: Łódź, Poland, 2008.

54. Świderek, M. (Ed.) Spacery po Zielonej Łodzi; Ośrodek Działań Ekologicznych Źródła: Łódź, Poland, 2004.

55. Świderek, M. (Ed.) Parki i Ogrody Województwa Łódzkiego; Ośrodek Działań Ekologicznych Źródła: Łódź, Poland, 2005.

56. Bartnik, A.; Suwart, A. The fountains of Łódź: Their relevance to the lives of its inhabitants. Tourism 2015, 25, 47-59. [CrossRef] 
57. Wycichowska, B. Łódzkie fontanny w przestrzeniach publicznych miasta. In Miasta Wracaja nad Wodę; Kosmala, M., Ed.; PZIiTS: Torun, Poland, 2011; pp. 99-112.

58. Wycichowska, B. Układy wodne w zabytkowych parkach Łodzi. Archit. Czas. Tech. 2012, 109, $213-222$.

59. Janiszewski, T.; Wojciechowski, Z.; Markowski, J. Atlas Ptaków Legowych Łodzi; Wydawnictwo Uniwersytetu Łódzkiego: Łódź, Poland, 2009.

60. Durecka, I. Parki Jako Element Struktury Przestrzennej Miast Łódzkiego Obszaru Metropolitalnego. Ph.D. Thesis, University of Lodz, Lodz, Poland, 2017.

61. Olbińska, K. The value of urban parks in Lodz. Real Estate Manag. Valuat. 2018, 26, 73-88. [CrossRef]

62. Czembrowski, P.; Kronenberg, J.; Czepkiewicz, M. Integrating non-monetary and monetary valuation methods-SoftGIS and hedonic pricing. Ecol. Econ. 2016, 130, 166-175. [CrossRef]

63. Czembrowski, P.; Łaszkiewicz, E.; Kronenberg, J. Bioculturally valuable but not necessarily worth the price: Integrating different dimensions of value of urban green spaces. Urban For. Urban Green. 2016, 20, 89-96. [CrossRef]

64. Czembrowski, P.; Kronenberg, J. Hedonic pricing and different urban green space types and sizes: Insights into the discussion on valuing ecosystem services. Landsc. Urban Plan. 2016, 146, 11-19. [CrossRef]

65. Łaszkiewicz, E.; Czembrowski, P.; Kronenberg, J. Can proximity to urban green spaces be considered a luxury? Classifying a non-tradable good with the use of hedonic pricing method. Ecol. Econ. 2019, 161, 237-247. [CrossRef]

66. Czembrowski, P.; Łaszkiewicz, E.; Kronenberg, J.; Engström, G.; Andersson, E. Valuing individual characteristics and the multifunctionality of urban green spaces: The integration of sociotope mapping and hedonic pricing. PLoS ONE 2019, 14, e0212277. [CrossRef] [PubMed]

67. Xiu, N.; Ignatieva, M.; van den Bosch, C.K.; Chai, Y.; Wang, F.; Cui, T.; Yang, F. A socio-ecological perspective of urban green networks: The Stockholm case. Urban Ecosyst. 2017, 20, 729-742. [CrossRef]

68. Łaszkiewicz, E.; Kronenberg, J.; Marcińczak, S. Attached to or bound to a place? The impact of green space availability on residential duration: The environmental justice perspective. Ecosyst. Serv. 2018, 30, 309-317. [CrossRef]

69. Borowska-Stefańska, M.; Wiśniewski, S. Dostępność łódzkich parków w świetle transportu indywidualnego, zbiorowego i rowerowego. Przeglad Komun. 2018, 73, 9-16.

70. Borowska-Stefańska, M.; Wiśniewski, S. Pedestrian accessibility to parks in Łódź. Stud. Miej. 2017, 27, 39-50. [CrossRef]

71. Wolch, J.; Wilson, J.P.; Fehrenbach, J. Parks and Park Funding in Los Angeles: An Equity-Mapping Analysis. Urban Geogr. 2005, 26, 4-35. [CrossRef]

72. Koprowska, K.; Kronenberg, J.; Kuźma, I.B.; Łaszkiewicz, E. Condemned to green? Accessibility and attractiveness of urban green spaces to people experiencing homelessness. Geoforum 2020, 113, 1-13. [CrossRef]

(C) 2020 by the authors. Licensee MDPI, Basel, Switzerland. This article is an open access article distributed under the terms and conditions of the Creative Commons Attribution (CC BY) license (http://creativecommons.org/licenses/by/4.0/). 